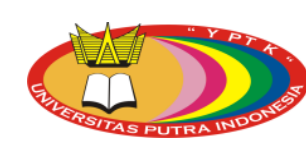

\title{
Sistem Informasi Madrasah Diniyah Mesjid Al-Marhamah Berbasis Online
}

\author{
Deval Gusrion \\ Universitas Putra Indonesia”YPTK” Padang, Indonesia \\ devalgusrion@gmail.com
}

\begin{abstract}
Madrasah Diniyah is a non-school religious educational institution that is expected to deliver Islamic education continuously beyond the teachings that already exist in regular school. As an educational institution, within it, there are several aspects such as grades and attendance that haven't been monitored well, especially by parents, thus these parent are in able to know the grades \& attendance of their children in the given time. With an online-based application, it is possible for parents, teachers and MDA management to know the knowledge development of these students (santri) through aspects such as grades, attendance, Al-Qur'an recitation and etc. , so the students achievements can be monitored well by teacher and parents.
\end{abstract}

Keyword : students, parents, attendance, online, application

\begin{abstract}
Abstrak
Madrasah Diniyah adalah salah satu lembaga pendidikan keagamaan pada jalur luar sekolah yang diharapkan mampu secara terus menerus memberikan pendidikan agama Islam kepada anak didik yang tidak terpenuhi pada jalur sekolah. Sebagai lembaga pendidikan terdapat beberapa item-item seperti nilai dan absensi yang belum termonitor dengan baik khususnya oleh orang tua, sehingga mereka belum dapat mengetahui pencapaian nilai dan absensi anak-anak mereka setiap saat. Dengan aplikasi yang berbasis online ini dapat membatu orang tua, pengajar/guru serta pengurus MDA untuk mengetahui perkembangan ilmu agama para santri mereka seperti : absensi, nilai lapor,Al-Qur'an, hafalan ayat dan lainnya sehingga pencapaian santri termonitor dengan baik oleh guru maupun orang tua.
\end{abstract}

Kata kunci : santri, orang tua, nilai, online, aplikasi

\section{PENDAHULUAN}

Madrasah Diniyah adalah suatu pendidikan keagamaan Islam nonformal yang menyelenggarakan pendidikan agama Islam sebagai pelengkap bagi siswa di pendidikan sekolah umum [1]. Kegiatan Madrasah Diniyah lebih banyak diadakan di mesjid-mesjid yang ada disekitar pemukiman warga/mayarakat, dari pantauan kami khususnya untuk kota Padang Madrasah Diniyah belum 


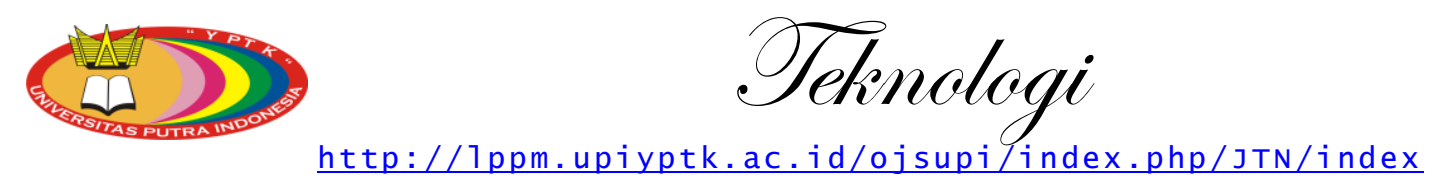

Vol. 9 Issue 12019

ISSN: 2301-4474| e-ISSN: 2541-1535

memiliki sistem yang terintegrasi dan dapat dimonitor secara langsung oleh guru maupun orang tua siswa.

Madrasah Diniyah yang merupakan sebagai alternatif yang dominan untuk melengkapi pelajaran keagamaan dirasakan perlu sebuah pengembangan sistem informasi, adapun sistim nanti yang dikembangkan adalah bagaimana sistem penilaian siswa madrasah dapat tersimpan dan termonitor oleh guru dan orang tua secara online. Dengan sistem informasi yang berbasis online diharapkan orang tua akan lebih mudah memantau pekerkambangan ilmu agama dari anak-anaknya begitu juga ustad dan ustadzah (guru) dapat mengetahui perkembangan ilmu agama anak didikannya karena pada sistem yang akan dibangun juga dilengkapi dengan modul monitoring kegiatan agama dirumah.

\section{Tinjauan Literatur}

Dalam penulisan jurnal ini, beberapa hal-hal atau teori yang dikemukakan yang berkaitan dengan permasalahan dan ruang lingkup sebagai landasan dalam permbuat jurnal seperti : sistem informasi, pemodelan dan UML, bahasa pemograman PHP dan database mysql.

\subsection{Sistem Informasi}

Sitem merupakan serangkaian prosedur sedangkan informasi merupakan data yag sudah diolah, jadi Sistem informasi (SI) adalah kombinasi dari orang-orang, perangkat keras, perangkat lunak, jaringan komunikasi, sumber daya data, dan kebijakan serta prosedur dalam menyimpan, mendapatkan kembali, mengubah, dan menyebarkan informasi dalam suatu organisasi [2].

Sistem informasi dikembangkan untuk tujuan yang berbeda-beda, tergantung pada kebutuhan bisnis. Sistem informasi memiliki beberapa manfaat diantaranya Meningkatkan efisiensi dan efektivitas data secara akurat dan realtime serta laporan yang komprehensif [3].

\subsection{Pemodelalan dan UML}

Unified Modeling Language (UML) merupakan salah satu alat bantu yang dapat digunakan dalam bahasa pemograman yang berorientasi objek. UML (Unified Modeling Language) yaitu keluarga notasi grafis yang didukung oleh meta-model tunggal, yang membantu pendeskripsian dan desain sistem perangkat lunak, khususnya sistem yang dibangun dengan menggunakan pemrograman berorientasi objek [4].

\subsection{Bahasa Pemograman PHP}

Bahasa pemograman berisikan insruksi-intruksi yang dimengerti oleh computer, ada banyak bahasa pemograman yang ada saat ini salah satunya adalah pemograman PHP. PHP adalah kependekan dari PHP:HyperText Preprocessor merupakan bahasa utama script server-side yang 


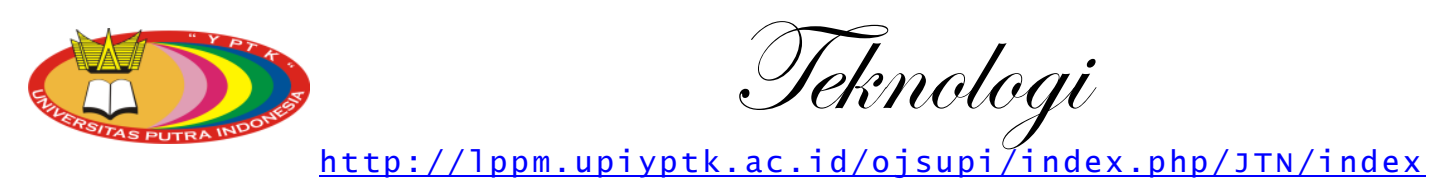

Vol. 9 Issue 12019

ISSN: 2301-4474| e-ISSN: 2541-1535

disisipkan pada HTML yang dijalankan di server, dan juga bisa digunakan untuk membuat aplikasi desktop [5]. PHP merupakan bahasa pemograman web yang paling banyak digunakan pada saat ini, banyak perusahaan besar menggunakan PHP, bahasa pemograman yang identik dengan logo gajah ini juga menjadi basis dari CMS terkenal seperti WordPress, Joomla dan Drupal.

\subsection{Database Mysql}

Database MySQL tergolong sebagai DBMS (Database Management System). DBMS adalah sistem yang secara khusus dibuat untuk memudahkan pemakai dalam mengelola basis data. MySQL merupakan sebuah perangkat lunak /software sistem manajemen basis data SQL atau DBMS Multithread dan multi user [6]. MySQL sebenarnya merupakan turunan dari salah satu konsep utama dalam database untuk pemilihan atau seleksi dan pemasukan data yang memungkinkan pengoperasian data dikerjakan secara mudah dan otomatis [7].

\section{Metodologi}

Metodologi penelitian yang digunakan meliputi :

a. Analisis

Studi literatur dengan teknik mengumpulkan data atau informasi dari guru dan orang tua santri, serta mempelajari sistem akademik madrasah sebagai dari dasar dari pengembangan penulisan jurnal ini.

b. Perancangan

Perancangan sistem dengan mengunakan PHP dan database MYSQL.

c. Implementasi

Sistem yang dapat diakses oleh pengurus, guru (ustad/ustadzah), maupun orang tua santri melalu internet mengunakan komputer maupun handphone.

d. Pengujian Simulasi

Aplikasi yang sudah disimulasi akan diuji untuk melihat bagaimana kinerjanya dan kemudian mengevaluasinya. Dengan evaluasi ini diharapkan solusi yang didapat, akan segera untuk diimplementasikan di lapangan.

\section{Hasil dan Diskusi}

\subsection{Analisa Sistem}

Jurnal yang disusun ini dengan judul sistem Informasi Madrasah Diniyah Berbasis Online, Prosedur dan aliran dokumen yang digunakan digambarkan dalam bentuk use case diagram, class diagram dan activity diagram.

\subsubsection{Use Case Diagram}




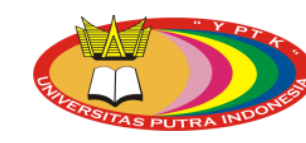

Use Case Diagram memberikan gambaran bagaimana interaksi antara sistem dengan pengguna atau aktor tentang aktivitas dan proses apa yang dapat dilakukan.

\section{a. Definisi Aktor}

Dalam aplikasi sistem informasi ini terdiri dari 4 aktor, yaitu : admin, pengurus, guru dan orang tua. Berikut defines actor yang terlibat dalam sistem :

Tabel 1 : Definisi Aktor

\begin{tabular}{|c|l|l|}
\hline No & \multicolumn{1}{|c|}{ Aktor } & \multicolumn{1}{c|}{ Deskripsi } \\
\hline 1. & Admin & Mengontrol jalannya sistem \\
\hline 2. & Pengurus & Pengurus berperan untuk melihat laporan MDA \\
\hline 3. & Guru & Guru Bertugas untuk menginput/mengedit nilai dan absen \\
\hline 4. & Orang Tua & $\begin{array}{l}\text { Oran tua berperan untuk mengontral perkembangan anaknya dan } \\
\text { menginput apakah anaknya melaksanaan tugas (sholat, mengaji dll) }\end{array}$ \\
\hline
\end{tabular}

\section{b. Diagram Use Case}

Berikut ini merupakan kegiatan-kegiatan yang dilakukan dalam pelaksanaan aktifitas sistem di MDA Mesjid Al-Marhamah berdasarkan uraian diatas yang digambarkan dengan use case diagram sebagai berikut :

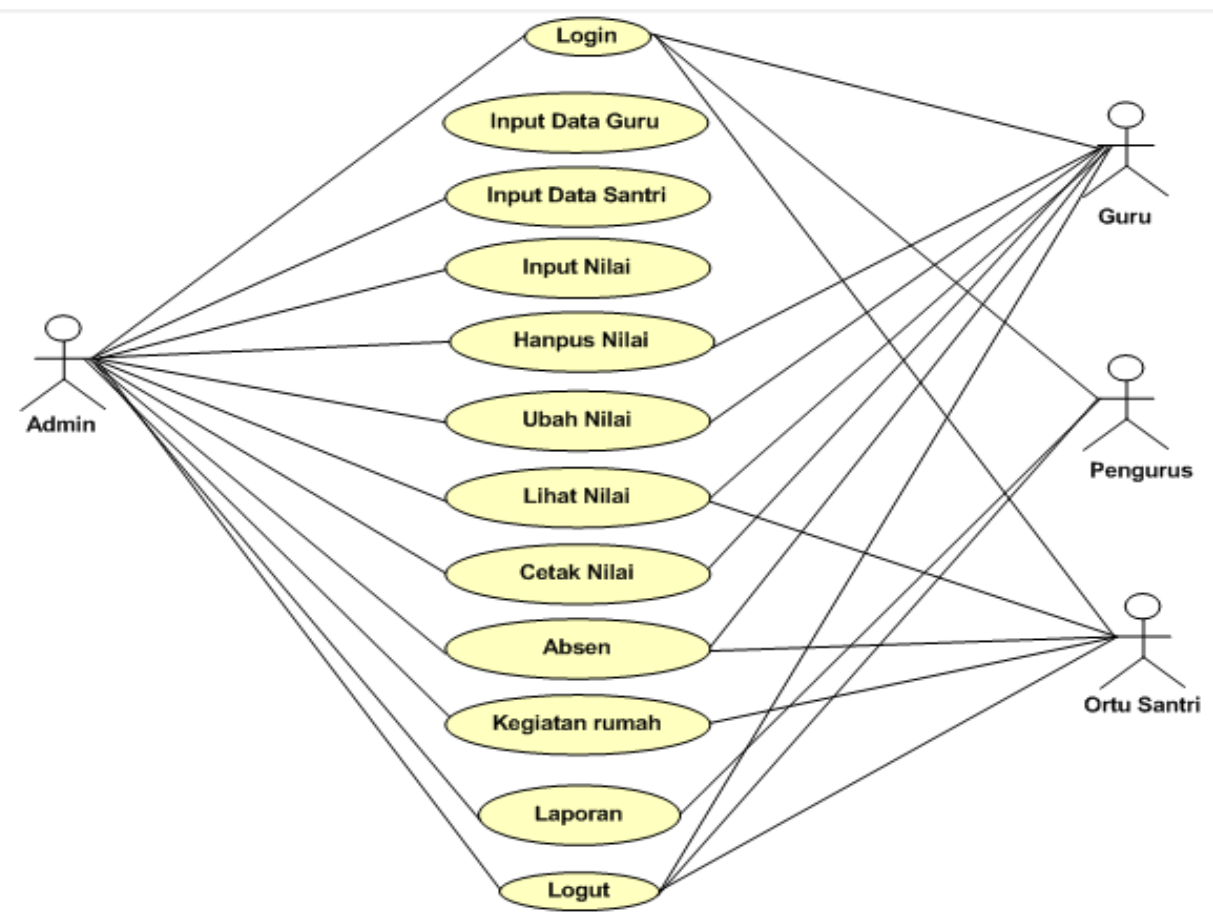




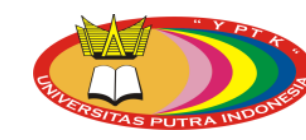

Gambar 1 : Use Case Diagram

\subsubsection{Class Diagram}

Selanjutnya untuk mengklasifikasikan atau menggambarkan dari kelas-kelas dapat dilihat pada Diagram Class, berikut gambar class diagram pada sistem informasi MDA Al-Marhamah yang berbasiskan online sebagai berikut :

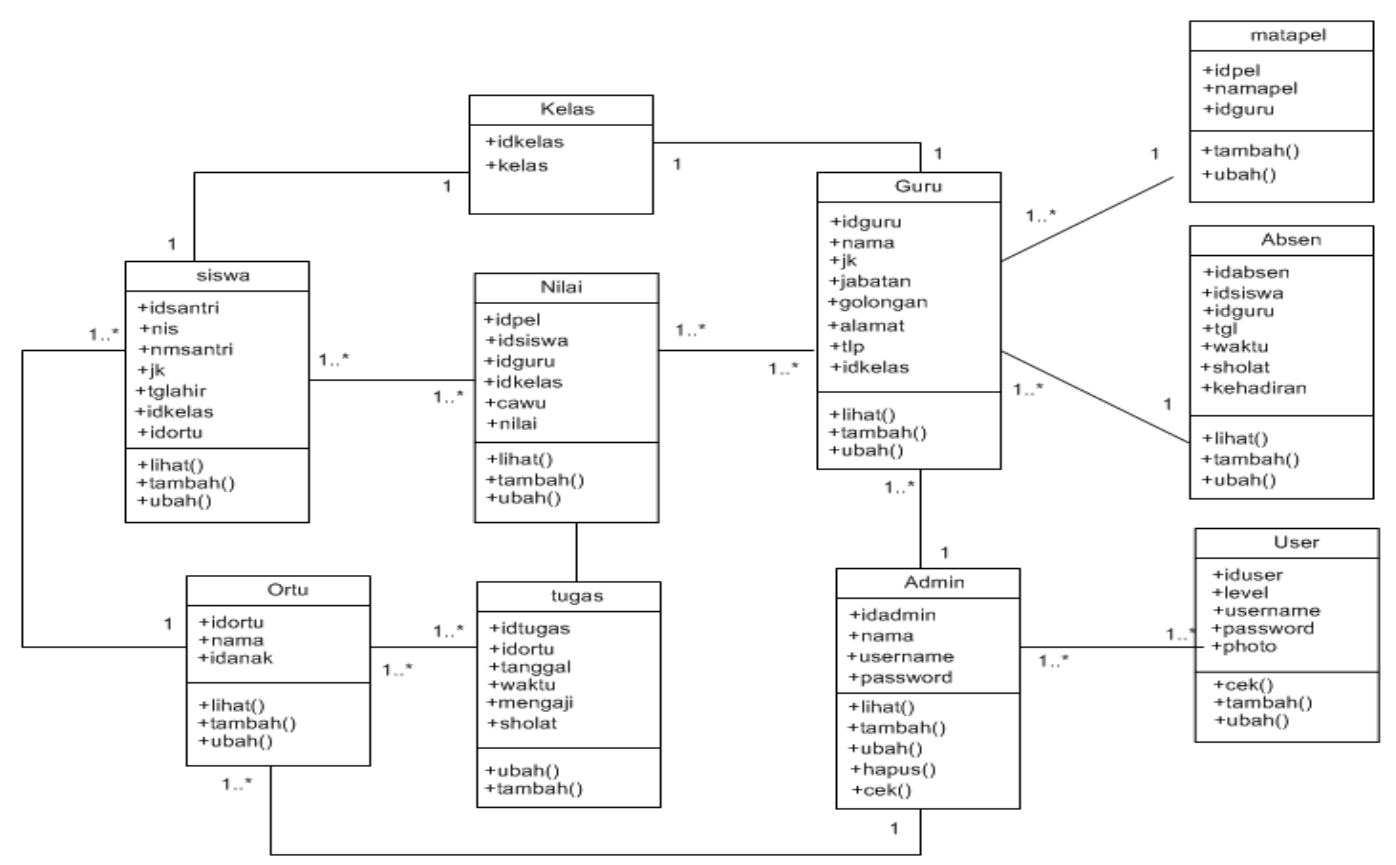

Gambar 2 : Class Diagram

\subsubsection{Activity Diagram}

a. Activity Diagram : Admin

Pada diagram aktifitas admin berfungsi untuk mengontrol dan mengendalikan sistem informasi MDA Al-Marhamah.

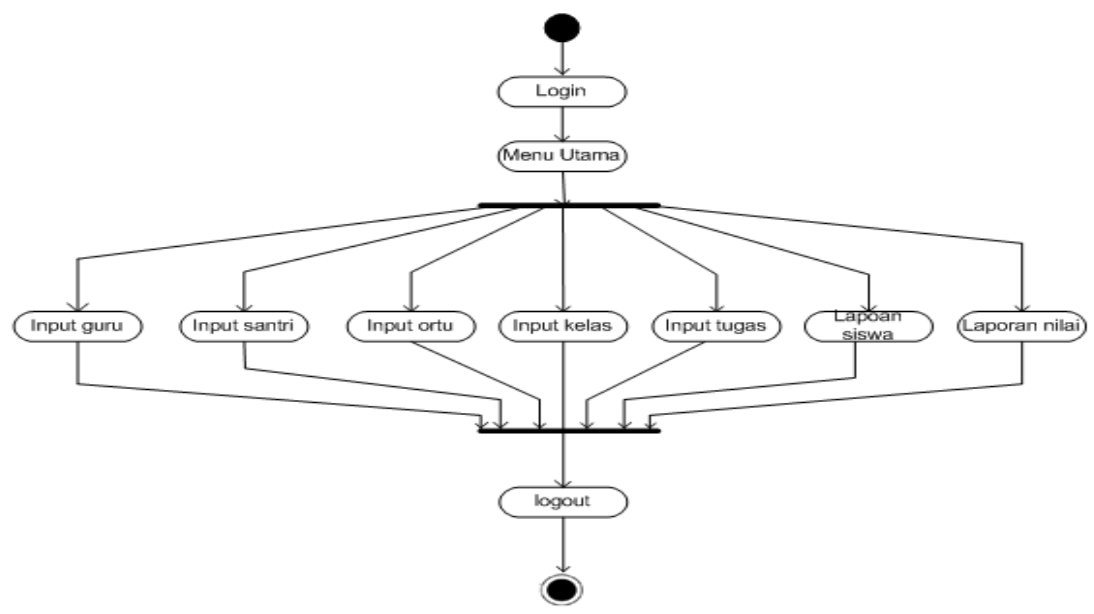




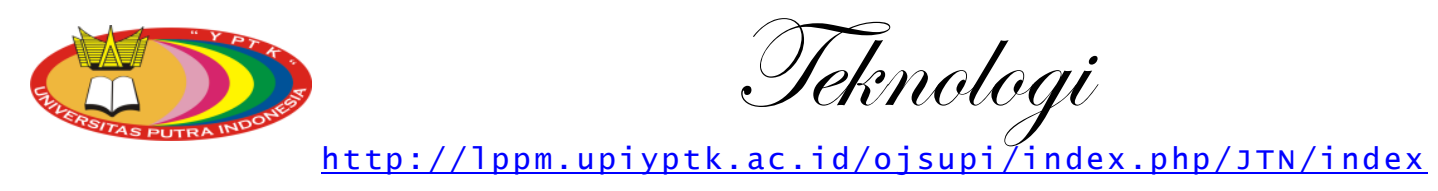

Vol. 9 Issue 12019

ISSN: 2301-4474| e-ISSN: 2541-1535

\section{Gambar 3 : Activity Diagram Admin}

b. Activity Diagram : Pengurus

Pada diagram aktifitas pengurus befungsi untuk menerima informasi-informasi yang berkaitan dengan MDA seperti laporan jumlah santri/siswa, nilai dan orang tua.

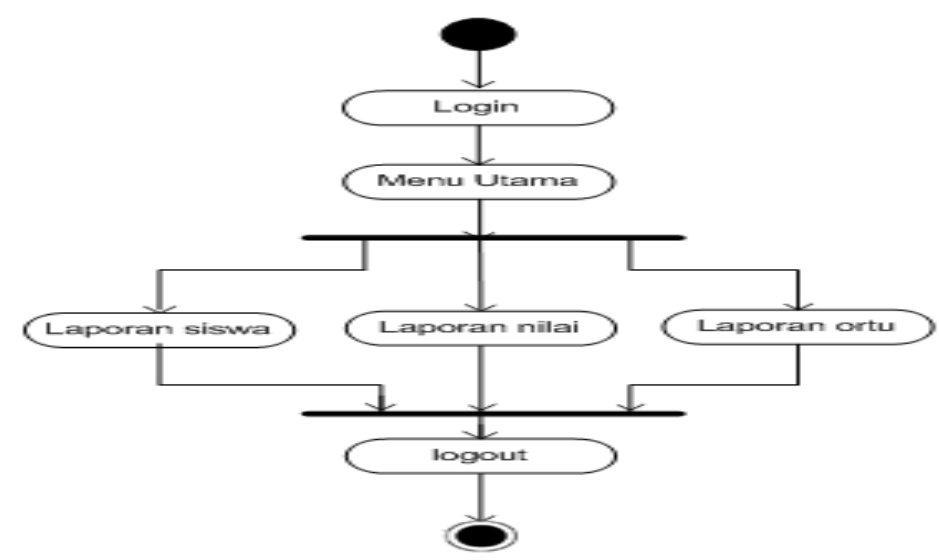

Gambar 4 : Activity Diagram Pengurus

c. Activity Diagram : Guru

Pada diagram aktifitas guru berperan untuk menginput nilai dan absen dari santri, sehingga nanti dapat dilihat secara online baik oleh pengurus dan orang tua santri.

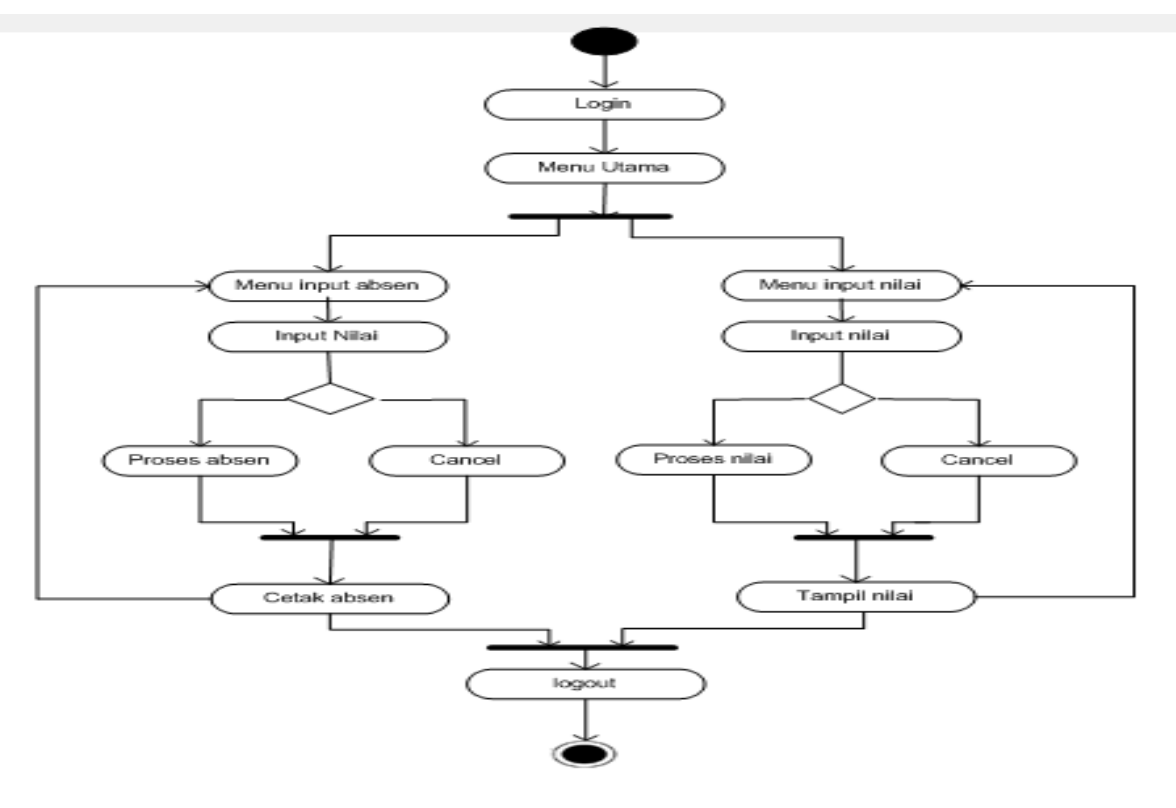




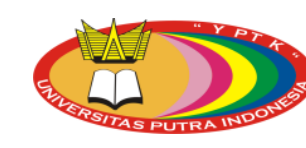

\section{Gambar 5 : Activity Diagram Guru}

d. Activity Diagram : Orang Tua

Pada diagram aktifitas orang tua, disini orang tua dapat mengetahui kemajuan nilai dari anaknya dan juga absensi. Selain mengetahui nilai dan absen, orang tua juga memiliki peran untuk menginput beberapa item kegiatan agama di rumah yang merupakan nilai tambahan yang akan diberikan oleh guru kepada santri.

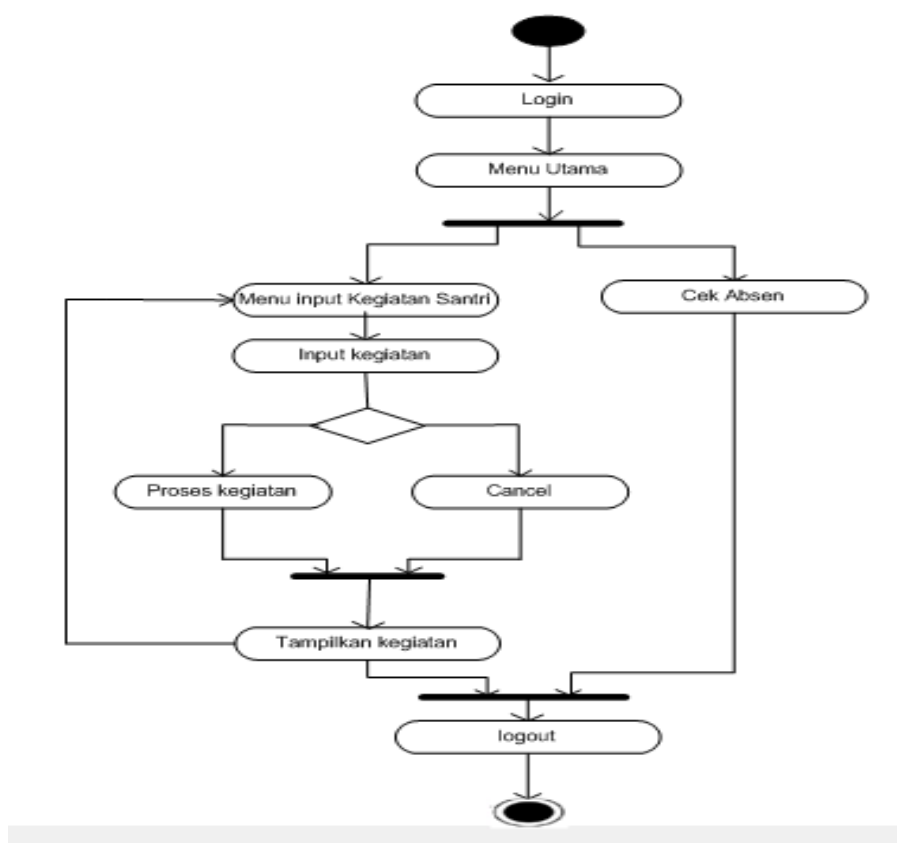

Gambar 6 : Activity Diagram Orang Tua

\subsubsection{Sequence Diagram}

a. Sequence Diagram : Input Data

Pada sequence diagram input data mengambarkan proses penginputan data-data pemegang user dan data lainnya pada sistem informasi.

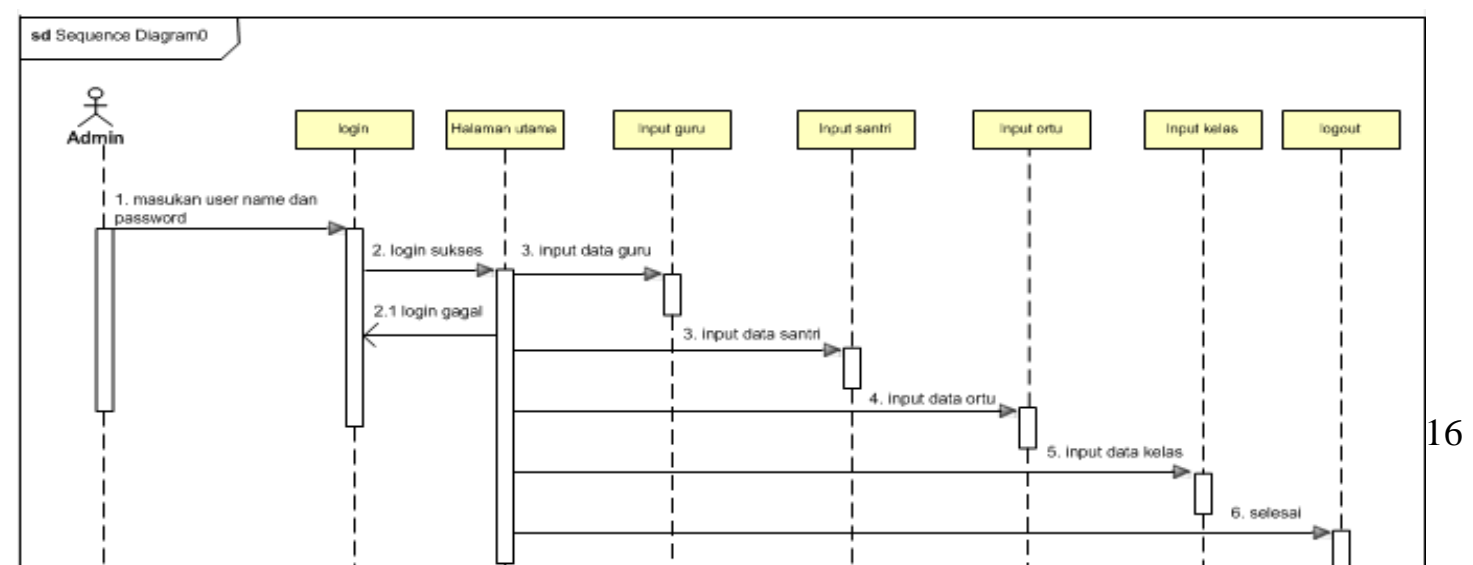




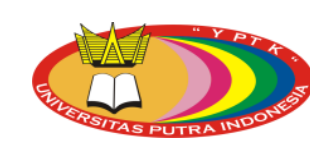

Gambar 7 : Sequence Diagram Input Data

b. Sequence Diagram : Input Nilai dan Absen

Pada sequence diagram input nilai dan absen mengambarkan proses penginputan nilai dan absen santri oleh guru.

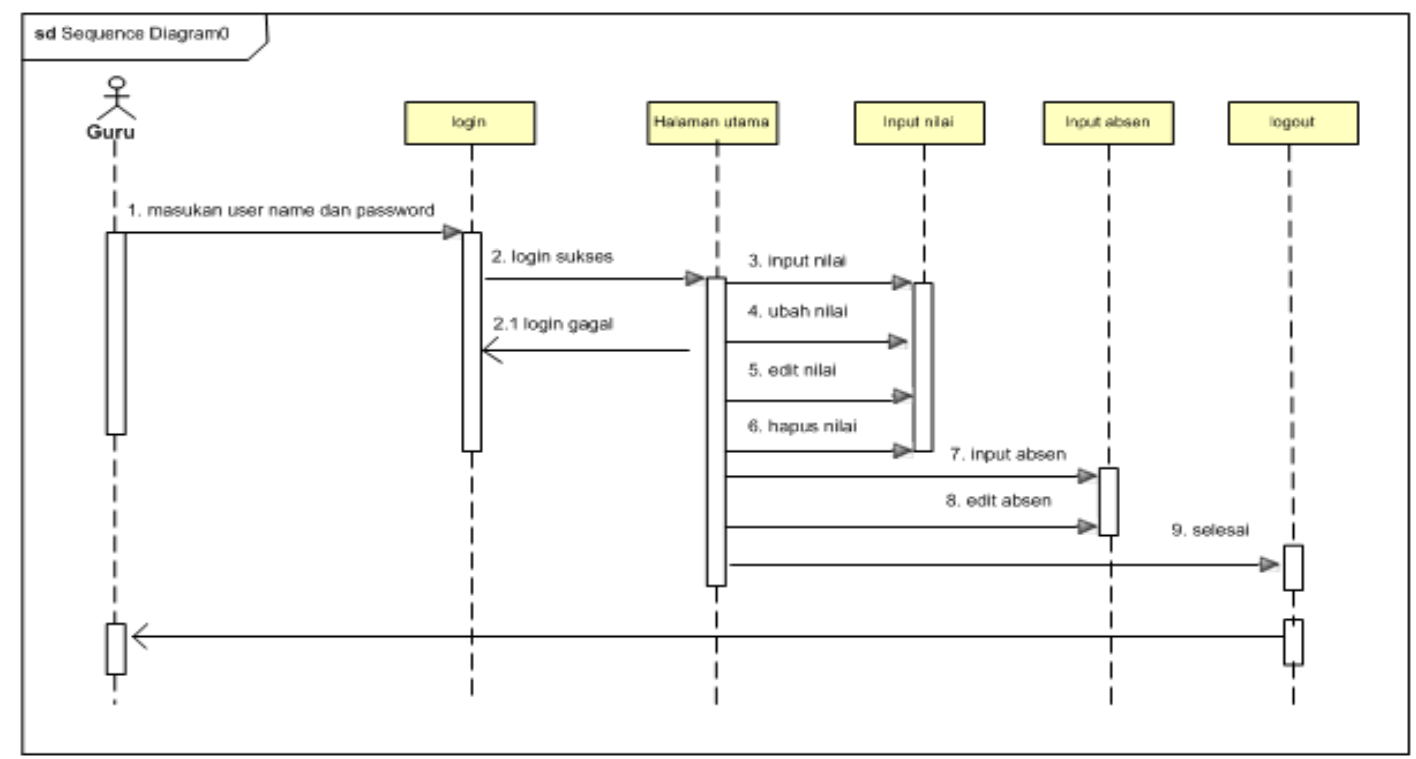

Gambar 8 : Sequence Diagram Input Absen dan Nilai

c. Sequence Diagram : Input Kegiatan Santri

Pada sequence diagram input tugas santri mengambarkan proses penginputan kegiatan santri dirumah seperti baca Al-Qur'an, hapalan ayat dan lainnya.

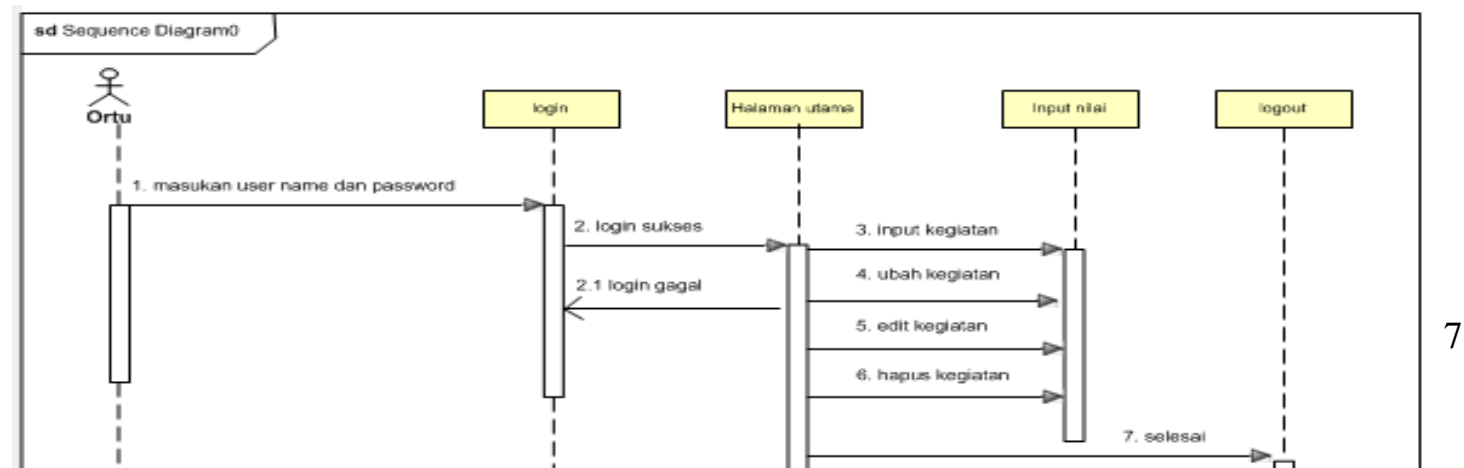




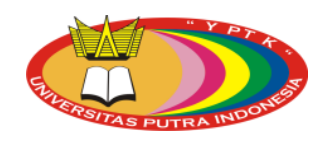

Gambar 9 : Sequence Diagram Input Kegiatan Santri

\subsection{Implementasi}

Adapun nantinya aplikasi sistem informasi ini dapat diakses dengan jaringan internet dengan media handphone dan laptop, adapun menu yang disediakan adalah sebagai berikut :

a. Menu Login

Menu login merupakan tampilan awal dari aplikasi sistem informasi MDA Almarhamah, digunakan untuk masuk kendalam aplikasi dengan tingkatan user yang berbeda-beda sesuai dengan level yang didaftarkan ke admin.

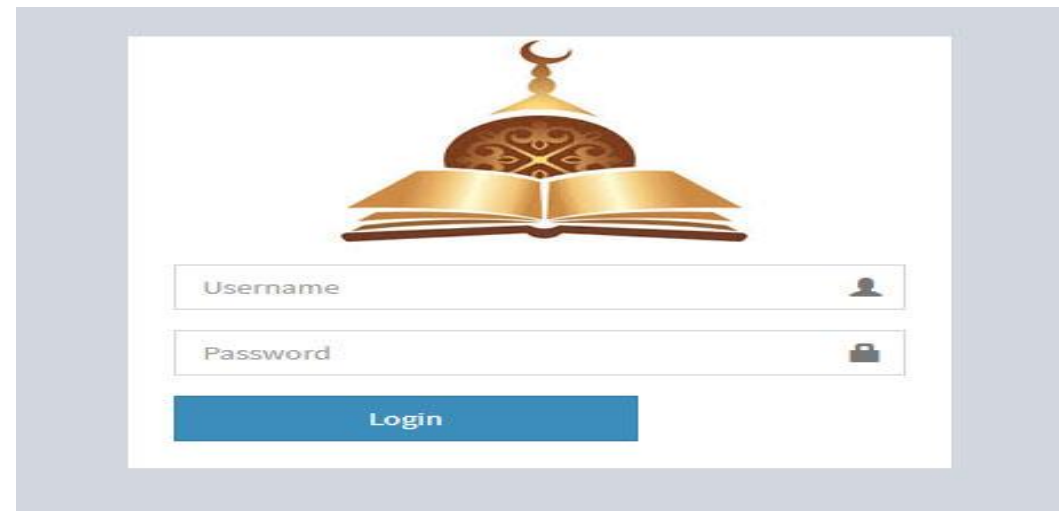

Gambar 10 : Halaman Login

b. Input Data Oleh Guru

Halaman Guru berisikan menu-menu untuk menginput nilai dan absen santri, selain menginput absen dan nilai terdapat juga menu untuk mencetak absen dan nilai.

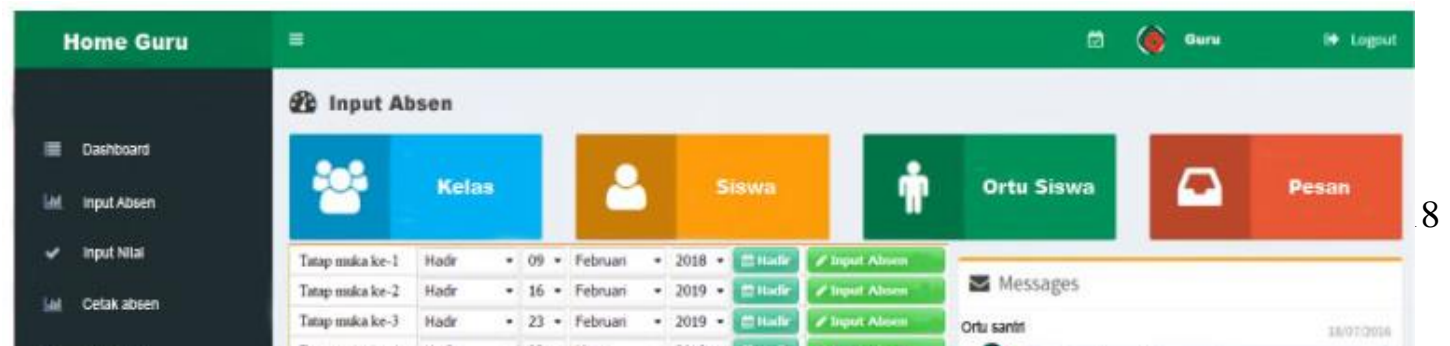




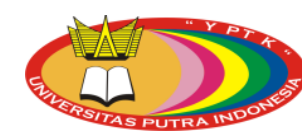

\section{Gambar 11 : Input Data Oleh Guru}

c. Input Data Oleh Orang Tua

Halaman Guru berisikan menu-menu untuk menginput nilai dan absen santri, selain menginput absen dan nilai terdapat juga menu untuk mencetak absen dan nilai :

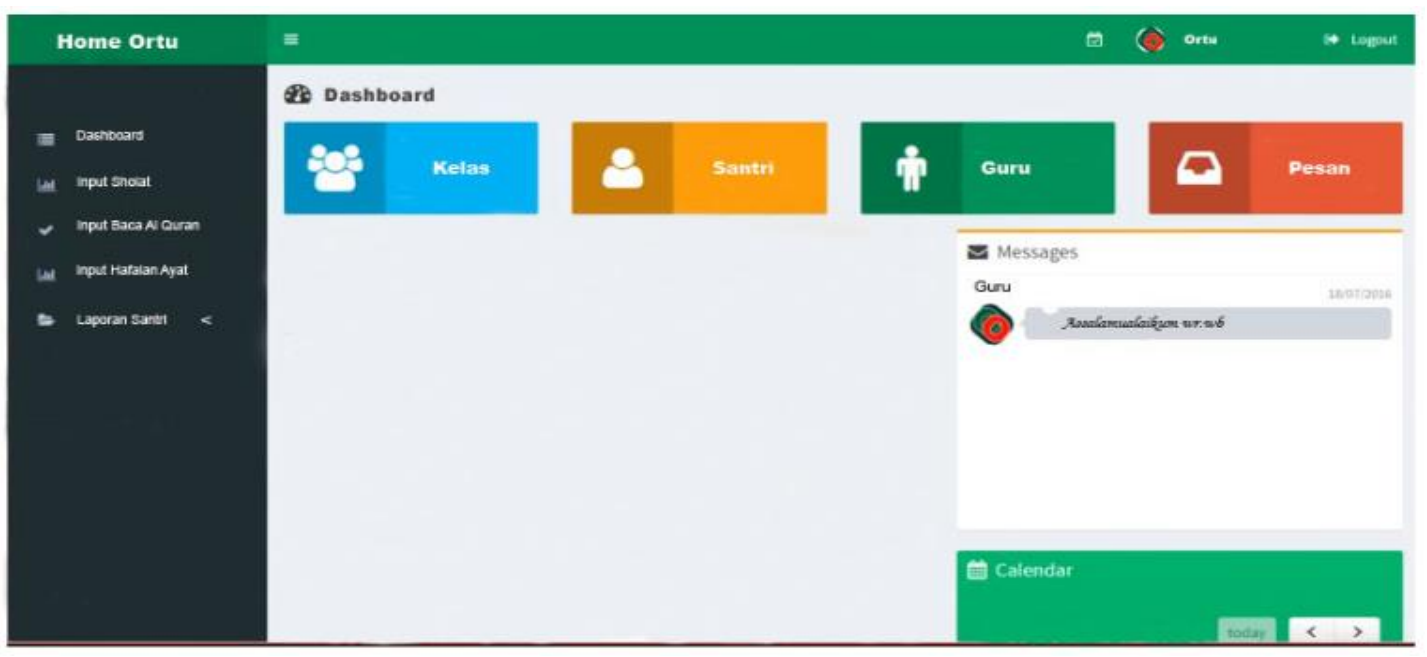

Gambar 12 : Input Kegiatan Santri Oleh Orang Tua

\section{Kesimpulan}

Sistem informasi madrasah diniyah mesjid al-marhamah yang berbasis online ini akan meningkatkan kualitas pengajaran di madrasah dan kedepannya diharapan semua madrasah yang ada di Indonesia memiliki sistem informasi yang dapat menunjang tugas guru yang selama ini masih dengan cara konvensional. Adapun manfaat aplikasi ini terutama bagi orang tua dapat 


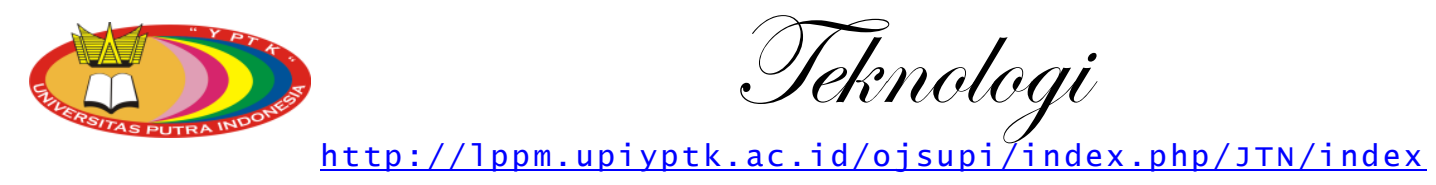

Vol. 9 Issue 12019

ISSN: 2301-4474| e-ISSN: 2541-1535

mengetahui informasi akademik anaknya dengan cepat dan mudah, selain untuk monitoring pencapaian anaknya orang tua juga berperan untuk menginformasikan kegiatan keagamaan anak mereka yang di input melalui sistem secara online supaya guru MDA memiliki referensi lainnya dalam pemberian nilai bagi santri mereka sehingga meningkatkan kualitas pengajaran dan penilaian. Dengan tampilan sistem yang user friendly dapat mempermudah orang tua, guru maupun pengurus dalam memahami penggunaan sistem, dan kedepannya dapat ditambahkan $e$ learning.

\section{Referensi}

[1] Amin,Haedar, El-saha Isham, "Peningkatan Mutu Terpadu Pesantren dan Madrasah Diniyah," Jakarta: Diva pustaka, 2004.

[2] Marakas, George M., dan James A. O'Brien, "Pengantar Sistem Informasi," Jakarta: Salemba Empat,2017.

[3] Tohari, Hamim, "Astah Analisis Serta Perancangan Sistem Informasi Melalui Pendekatan UML," Yogyakarta: Andi,2017.

[4] Fowler, Martin, "UML Distilled : Panduan Singkat Bahasa Pemodelan Objek Standar," Yogyakarta: Andi,2005.

[5] Sidik, Betha, "Pemrograman Web dengan PHP7," Bandung: Informatika Bandung,2017.

[6] Kadir, Abdul, "Mudah Mempelajari Database MySQL," Yogyakarta: Andi,2010.

[7] Kadir, Abdul, dan Terra Ch. Triwahyuni, “ Pengantar Teknologi Informasi Edisi Revisi 2,” Yogyakarta: Andi,2013.

[8] A.S., Rosa, dan M. Shalahuddin, "Rekayasa Perangkat Lunak : Terstruktur dan Berorientasi Objek," Bandung: Informatika Bandung,2015. 